\title{
TEOLOGICZNE I PRAWNE ASPEKTY KONFERENCJI BISKUPÓW
}

Od pewnego czasu dyskutuje się powszechnie nad dokumentem rozesłanym jako instrumentum laboris konferencjom biskupów przez Kongregację ds. Biskupów z prośbą o zajęcie stanowiska ${ }^{1}$. Dokument ten zajmuje się zagadnieniem prawnego i teologicznego uporządkowania oraz jakością konferencji biskupich, jako problemem omawianym na II soborze watykańskim, a uwzględnionym także w nowym kodeksie prawa kościelnego z roku 1983. Synod biskupów w roku 1985 zajął się również konferencjami biskupimi i polecił zbadać ich teologiczne miejsce oraz rozwinąć jaśniej i głębiej zagadnienie ich nauczycielskiego autorytetu ${ }^{2}$.

Nowy kodeks prawa kościelnego przytacza w 114 miejscach wyrażenie „conferentia episcoporum” i zawiera własny rozdział: De episcoporum conferentiis (kan. 447 - 458). Kodeks prawa kanonicznego z roku 1917 znał instytucję konferencji biskupów (por. kan. 292), lecz chodziło tu o zgromadzenie biskupów prowincji kościelnej, którzy powinni się spotkać na zaproszenie metropolity co pięć lat w celu omawiania wspólnych problemów i przygotowania ewentualnego synodu prowincjalnego (kan. $292 \S 1)^{3}$.

Konferencja biskupów — tak jak ją określa nowy Kodeks prawa kanonicznego - jest jednak zgromadzeniem biskupów jednego narodu albo określonego terytorium (por. kan. 447). Tym samym staje się jasne, że instytucja, która

* Tekst poniższego referatu został wygłoszony po niemiecku w Papieskiej Akademii Teologicznej w Krakowie 6 V 1989 r.

${ }^{1}$ Por. A. Dulles, J. A. Komonchak, L. Örsy, J. H. Provost, [w:] „America” 19. 3. 1988 , s. $293-304$.

2 Kirche - unter dem Wort Gottes - feiert die Geheimnisse Christi - zum Heil der Welt. Schlußdokument der Zweiten außerordentlichen Synode, 9. Dezember 1985; tłumaczenie niemieckie w: W. Kas p e r, Zukunft aus der Kraft des Konzils. Die außerordentliche Bischofssynode '85, Freiburg 1986, s. $19-45$.

${ }^{3}$ Por. P. Kr ämer, Theologisch-rechtliche Begründung der Bischofskonferenz, [w:] Traditio und Communio, Festheft für Hans Dombois zum 80. Geburtstag, hrsg. von P. La n da u, „Zeitschrift für Evangelisches Kirchenrecht" 32:1987, s. 402 — 422. 
w Kodeksie prawa kanonicznego z roku 1917 nie miała żadnego znaczenia prawnego, nabrała ważności przy reformie prawa kościelnego.

A cóż się wydarzyło? Tu, jak i w niektórych innych rozstrzygnięciach prawnych, wyraźnie zaznaczyło się to, do czego zmierzał papież Jan XXIII, zwołując II sobór watykański. Sobór ten powinien być nie tylko pastoralny, lecz także stworzyć impulsy do reformy kodeksu prawa kościelnego ${ }^{4}$. Jest to nader widoczne w odniesieniu do rozwoju i prawnego ustawienia konferencji biskupich. W przedstawionych poniżej rozwiązaniach będzie chodziło najpierw o historyczne uzasadnienie i rozwój tej instytucji, którą określa się jako „konferencja biskupów", a następnie o uporządkowanie i ustawienie zarówno prawne, jak i teologiczne aktualnych problemów.

\section{II}

O historycznym rozwoju konferencji biskupów w waszym kraju, w Polsce, nie mogę wiele powiedzieć. Chciałbym tylko przypomnieć interwencję polskiego prymasa kard. S. Wyszyńskiego w auli soborowej. Wskazał on na fakt, że polska konferencja biskupów mogła dopiero wtedy powstać, kiedy Polska odzyskała swą niepodległość. Pierwsza konferencja biskupów odbyła się w 1917 r. Decyzje tych konferencji mają bardziej moralną niż prawną naturę ${ }^{5}$.

Parę uwag chciałbym poświęcić rozwojowi tej instytucji w Niemczech. W XIX wieku w kontekście walki o wolność Kościoła wobec państwowej uzurpacji, biskupi niemieccy spotkali się w Würzburgu po raz pierwszy w 1848 r. na zaproszenie i pod przewodnictwem arcybiskupa Kolonii Jana Geissela. Zgromadzenie to miało przedyskutować główne problemy, który wynikły dla Kościoła z przygotowanej w roku 1848 we Frankfurcie konstytucji Rzeszy niemieckiej. Gwarantowana w tej konstytucji wolność wiary i religii oraz sformułowana także wolność Kościoła pod kontrolą państwową — z konieczności pubudziły biskupów do ukształtowania otwierającej się przestrzeni wolności. Stary mistrz monachijski prawa kanonicznego Klaus Mörsdorf powiada, że nowe odniesienie pomiędzy Kościołem i państwem otwarło drogę „do przyjęcia kościelnych zadań przez Kościół i domagało się zarazem od biskupów koordynacji ich wysiłków"6. Biskupi zaaprobowali przyznane im przez nową konstytucję zadania i odpowiednio zadziałali. Mianowicie sięgnęli ponownie do synodalnego czynnika w Kościele, który na skutek historycznego rozwoju - ale prawdopodobnie także na skutek państwowej ingerencji - został bardzo nadwyrężony. Chociaż więc prawo kościelne nie dysponowało żadną normą prawną dla

${ }^{4}$ Zob. przemówienie Jana XXIII, wygłoszone 25 stycznia 1959 („Acta Apostolicae Sedis” $51: 1959$, s. $65-69)$.

5 Acta synodalia Vaticana II 5, congregatio generalis LXVII, 14 XI 1963, s. $193-195$. s. 390 .

6 K. Mörsdorf, Lehrbuch des Kirchenrechts, t. 1, München - Paderborn-Wien 1964, 
tego rodzaju zgromadzenia biskupów, to jednak można tu mówić „o parakanonicznym" tworze ${ }^{7}$. Konferencja biskupów niemieckich, która w roku 1848 została zwołana ad hoc, mogła się dzięki temu umocnić, mimo że nie rozwinęła jednoznacznej struktury prawnej. W swoim dalszym rozwoju zyskała ona na znaczeniu głównie w walce Kościoła z narodowym socjalizmem. To zgromadzenie biskupów niemieckich (brali w nim udział tylko biskupi rezydencjalni, nie zaś biskupi pomocniczy) utrwaliło swoją strukturę; ponieważ zaś biskupi gromadzili się w Fuldzie przy grobie św. Bonifacego, misjonarza niemieckich plemion, przeto mówiło się o „fuldańskiej konferencji biskupów” (Fuldauer Bischofskonferenz). Wprawdzie instytucja ta również w Kodeksie prawa kanonicznego z 1917 r. nie otrzymała prawnych podstaw, to jednak tworzyła strukturę usprawiedliwioną przez synodalny składnik Kościoła. Konferencji biskupów nie przysługiwało prawo decyzji, mimo to wspólne oświadczenia czy wspólne uzgodnienia miały dla niemieckich biskupów duże znaczenie.

Kard. Frings, arcybiskup koloński i przewodniczący konferencji biskupów niemieckich, w wypowiedzi na II soborze watykańskim wskazał na historyczny rozwój, faktyczne znaczenie i prawne aspekty konferencji biskupiej („Misereor”, „Adveniat” - biskupie dzieła pomocy katolików niemieckich powstały dzięki decyzji konferencji biskupów). Jednocześnie kardynał wyraźnie stwierdził, że każdy biskup swoją diecezją rządzi ,iuxta conscientiam suam et iuxta normas iuris”. Decyzje konferencji „non habebant nec habent vim iuridicam"8.

Prawne stanowisko biskupa rezydencjalnego nigdy nie zostało przez jakąś deklarację konferencji ograniczone, ponieważ ona prawnie nie mogła go ograniczyć. Decyzje konferencji biskupów nabierały dopiero wtedy znaczenia prawnego, gdy dany biskup uczynił je wiążącymi dla swojej diecezji. Stąd też nie mówiono o konferencji biskupów jako instytucji, lecz o konferencjach biskupów jako rocznych zgromadzeniach biskupów niemieckich pod kierownictwem wybranego przewodniczącego.

\section{III}

Sprawa uprawomocnienia konferencji biskupich nabrała nowej perspektywy, kiedy II sobór watykański zajął się tymi konferencjami, z którymi dotąd dobre doświadczenia mieli nie tylko biskupi niemieccy, lecz także polscy, francuscy, kanadyjscy i północnoamerykańscy. Konstytucja Sacrosanctum concilium uprzedziła - jako pierwsza - prawne unormowanie konferencji biskupich, prawdopodobnie oczekiwane przez ojców soborowych. Według artykułu

${ }^{7}$ Por. tamże, s. 390.

${ }^{8}$ Acta synodalia Vaticana II 5, congregatio generalis, 13 XI 1963, s. 66. 
22. tego dokumentu, konferencjom biskupim, legalnie ustanowionym i kompetentnym na określonym terytorium („territoriales episcoporum coetus”), zostało przyznane prawo w zakresie kształtowania liturgii. Pojęcie „conferentia episcoporum", występujące następnie w dekrecie Christus Dominus (przede wszystkim art. 37 i 38), jako zrozumiałe samo przez się, ma właśnie tutaj swoje źródło. „Konferencja biskupów” otworzyła trwałe miejsce w dekrecie o biskupach, gdzie przydzielono jej różnego rodzaju zadania. Art. 37 dekretu Christus Dominus stwierdza, że zorganizowane w licznych krajach konferencje biskupie przyniosły ,praeclara apostolatus argumenta”, tak że sobór uważa za wskazane spotykanie się biskupów tego samego kraju czy terytorium w tych gremiach.

Nie jest zadaniem niniejszych rozważań przedstawić kompetencje konferencji biskupich, zawarte w dekrecie o biskupach i w innych dokumentach soborowych, zwłaszcza w dekrecie o apostolstwie świeckich (Apostolicam actuositatem). Tak samo nie jest naszym zadaniem przedstawić prawne kompetencje konferencji biskupich w szczegółach, które zostały sformułowane w Kodeksie prawa kanonicznego.

Należy jedynie stwierdzić, że na długo przed II soborem watykańskim poczynione doświadczenia doprowadziły w poszczególnych krajach, dzięki wspólnym krajowym zgromadzeniom biskupów, do tego, że tym zgromadzeniom zostało przyznane trwałe miejsce, określone zadania i pewne kompetencje wewnątrz ustroju Kościoła, przy czym w sformułowaniach Kodeksu prawa kanonicznego widać, że prawo Stolicy Apostolskiej jest zapewnione przez konieczną approbatio lub recognitio wydanych rozporządzeń konferencji biskupich.

Należy jeszcze wskazać tutaj na to, że konferencja biskupów jest zgromadzeniem biskupów, to znaczy, że święcenia biskupie stanowią warunek przynależności. Nie jest ona już zatem — jak to było w historii konferencji biskupów niemieckich - tylko zebraniem biskupów rezydencjalnych (ordinarii locorum). Wynika z tego, że także biskupi pomocniczy mają prawo uczestnictwa; o prawie ich głosu rozstrzygają statuty odnośnych konferencji biskupich (por. art. $38 \mathrm{nr} 2 \mathrm{CD}$ i kan. $454, \S 1-\S 2$ CIC).

$\mathrm{Z}$ ustanowienia konferencji biskupich jako gremiów dysponujących kompetencjami dotyczącymi określonego narodu albo terytorium, co stało się wiążące dla całego Kościoła (por. Christus Dominus, 38; kan. 447 CIC), musiało z konieczności wyłonić się pytanie o ich prawne i teologiczne unormowanie, ponieważ conferentia episcoporum $\mathrm{z}$ jednej strony ma swoje odniesienie do collegium episcoporum, a z drugiej - do opowiedzialności danego biskupa ordynariusza (episcopus dioecesanus). Jego prawa, zobowiązania i odpowiedzialność nie mogą być zniesione przez odpowiedzialność konferencji biskupów. I ta sama conferentia episcoporum nie jest $\mathrm{z}$ kolei identyczna $\mathrm{z}$ collegium episcoporum, które połączone z głową - następcą św. Piotra - posiada odpowiedzialność za cały Kościół. 
Jeżeli zatem synodus episcoporum — również z ustanowienia II soboru watykańskiego - nie zastępuje collegium episcoporum, o tyle bardziej nie czyni tego conferentia episcoporum. Oczywiście w okresie posoborowym nastąpiły wydarzenia, które teraz z konieczności stawiają problem prawnego, zwłaszcza teologicznego, statusu konferencji biskupów. Uwidacznia to projekt dokumentu opracowanego przez kongregację biskupów i przesłanego konferencjom biskupim, a także dyskusja na jego temat. Przy rozpatrywaniu tej dyskusji ograniczę się z konieczności do niektórych stanowisk, zajętych w niemieckojęzycznych publikacjach, aczkolwiek dotychczasowa na ten temat dyskusja o zasięgu światowym, rozwinęła się — rzecz zrozumiała — zgodnie z oczekiwaniem.

\section{IV}

Dwadzieścia lat po zakończeniu II soboru watykańskiego synod biskupów, który próbował naszkicować bilans posoborowego rozwoju, zajął się także rozwojem konferencji biskupich. Stwierdzono wówczas: „W swoim sposobie postępowania muszą konferencje biskupie brać pod uwagę dobro Kościoła, względnie posługę dla jego jedności i wciąż aktualną odpowiedzialność każdego biskupa w stosunku do Kościoła światowego i do Kościoła lokalnego"9. Sformułowanie powyższe wskazuje na istnienie napięcia zarówno pomiędzy konferencją biskupów i Kościołem powszechnym, jak i pomiędzy biskupem, Kościołem powszechnym i Kościołem lokalnym. Należy dokładniej zbadać to napięcie pod względem teologicznym i prawnym.

\section{V}

Różnice zdań, dotyczące konferencji biskupich, można krótko ująć w następującym stwierdzeniu: według jednego poglądu konferencje biskupie są tylko pastoralnymi organami doradczymi. Ten pogląd, pozbawiony wprawdzie pokrycia w obecnym prawie kościelnym, nie kwestionuje autorytetu pojedynczego biskupa rezydencjalnego, ale też nie przyznaje konferencji biskupiej powagi nauczycielskiej i wychodzi za bardzo naprzeciw obawom przed lokalną i narodową samodzielnością w stosunku do powszechnego Kościoła.

Inny pogląd widzi w konferencji biskupów hierarchiczną instancję pośrednią pomiędzy Kościołem lokalnym i Kościołem powszechnym, nie wypierającą starych, rozwiniętych w historii Kościoła form synodów prowincjalnych i partykularnych, lecz pragnący je powiększyć o inne gremium. Według niego konferencja biskupów jest wyposażona w słuszny autorytet nauczycielski, jednak-

${ }^{9}$ Por. Kasper, jw., s. 36 n. 
że powinna się wystrzegać niebezpieczeństwa, które prowadziłoby do zniesienia władzy biskupiej mającej swe źródło w ius divinum.

Poglądy te, występujące obecnie w publikacjach na niemieckim obszarze językowym, nie są nowe, Te same poglądy i sprzeczności pojawiły się wyraźnie już w soborowej dyskusji. Sobór jednak zostawił te kwestie otwarte; uwidaczniają to sformułowania Lumen gentium (art. 23) i Christus Dominus (art. 38). Tym samym jednak sam problem nie został rozwiązany, napięcie nie zostało usunięte, a tylko przesunięte. O tym, że problem czekał na rozwiązanie, pokazuje dzisiejsza dyskusja.

\section{VI}

W nawiązaniu do niemieckojęzycznych publikacji, spowodowanych dokumentem kongregacji biskupów, można sprowadzić omawianą problematykę do trzech pytań:

1. Czy konferencja biskupów jest collegium, w sensie - collegium episcoporum, i tym samym, czy ma teologiczne uzasadnienie?

2. Jak rozgraniczyć status prawny konferencji biskupiej w stosunku do partykularnego i prowincjalnego synodu? Jakie znaczenie prawne jej przypada?

3. Czy konferencja biskupów posiada nauczycielski autorytet?

\section{ad 1: Uzasadnienie teologiczne}

Należy wyjść z teologicznej jakości święceń biskupich, „z pełni sakramentu święceń" - jak powiada II sobór watykański. Święcenia biskupie udzielają władzy uświęcania (munus sanctificandi), także władzy nauczania (munus docendi) i władzy urządzenia (munus regendi), które jednak — ze względu na swą naturę - tylko w hierarchicznej wspólnocie z głową i członkami kolegium mogą być sprawowane (LG 23; por. kan. 336). Władza święta (potestas sacra) jest dawana poszczególnemu biskupowi; ta władza włącza go w większą wspóInotę, w kolegium biskupów, które jest powiązane z głową.

Dokument studyjny kongregacji biskupów wychodzi od tego, że teologiczne znaczenie biskupiej kolegialności może być uzasadnione tylko całym kolegium biskupów. Ta biskupia kolegialność — o której mówi II sobór watykański — wtedy tylko jest w pełni dana, jeżeli kolegium w swojej pełnej postaci, jako następca kolegium apostolskiego, podejmuje odpowiedzialne rozstrzygnięcia dla całego Kościoła. Pełne urzeczywistnienie kolegialności, jako następstwa kolegium apostolskiego, ma uzasadnienie w prawie Bożym (ius divinum), jest uzasadnione nauką Chrystusa, jako Pana Kościoła. Tylko tam, gdzie kolegium biskupów wiąże się czynnie z głową, można tę kolegialność teologicznie uzasadnić. Władza kolegium w oparciu o swoją teologiczną podstawę według kan. 
37 jest sprawowana w następujących okolicznościach: na ekumenicznym soborze (kan. 337 § 1) i podczas zjednoczonego działania urzędowego rozsianych po świecie biskupów, o ile to działanie jest prowadzone przez papieża, albo przez niego przyjęte (kan. 337 § 2). Tylko wówczas, gdy kolegium jest w ten sposób czynne - twierdzi dokument studyjny, dotyczący konferencji biskupów - jego działalność ma teologiczny charakter we właściwym sensie tego słowa; jest działalnością iure divino.

Już w roku 1969 pisał Józef Ratzinger: „Nierzadko można spotkać mniemanie, że konferencjom biskupim nie przysługuje teologiczny wymiar [...] Pojęcie kolegialności pozwala się zastosować tylko do działającego w zjednoczeniu całego episkopatu”; i dalej: „Musimy raczej powiedzieć, że pojęcie kolegialności, obok funkcji jednoczenia, która przysługuje papieżowi, wskazuje na wielowymiarowy, w szczególach zmieniający się element, który zasadniczo należy do ustroju Kościoła, ale na różne sposoby może się urzeczywistniać [..] Konferencje biskupie są więc jedną z możliwych realizowanych form kolegialności"10. Jednakże kard. Ratzinger zdystansował się później od tej wypowiedzi i zakwestionował teologiczne uzasadnienie konferencji biskupich ${ }^{11}$.

Inaczej sądzi Walter Kasper, dogmatyk z Tübingi. Na ten temat wypowiedział się następująco: „Pełne urzeczywistnienie kolegialności jest iure divino; częściowe urzeczywistnienia kolegialności, do której należą synod biskupów i konferencje biskupie, nie mają tej samej teologicznej obowiązywalności. Mają natomiast teologiczny fundament; są one znakiem i narzędziem do urzeczywistnienia kolegialności w pełnym sensie. Konkretnie są one tylko z kościelnego prawa"12. Tym samym — sądzi Kasper — teologiczna ranga konferencji biskupich jest rangą mniejszego rzędu. Kanoniście nie jest łatwo określić dokładniej tę kwalifikację. Swego czasu sformułował ją bez wątpienia Karl Rahner: ius humanum, jeżeli nie powstało z samowoli, musi mieć uczestnictwo w prawie Bożym $^{13}$, pozostaje jednak tym samym ius humanum. Powiązanie ius humanum i prawa Bożego, utworzone przez Kaspra, nie jest łatwe do przyjęcia.

Kościół powszechny i Kościół lokalny wyznaczają teologiczną większość kątową ustroju Kościoła. Biskupia władza nad Kościołem lokalnym i powszechna władza papieża oraz złączonego z nim kolegium biskupów są z prawa Bożego. Wszystkie pośrednie instancje - mimo że mają duże znaczenie dla ustrojowego prawa kościelnego — opierają się na czysto kościelnym prawie. Zdobywają one swoją jakość w teologicznym ugruntowaniu swoich członków, to zna-

10 J. R a tzinger, Das neue Volk Gottes. Entwurf zu einer Ekklesiologie, Düsseldorf 1969, s. 222.

11 J. Ratzinge r, Zur Lage des Glaubens. Ein Gespräch mit V. Messori, München 1985, s. 60; zob. także H. de Lu b a c, Quellen kirchlicher Einheit, Einsiedeln 1974, s. 81 — 90.

$12 \mathrm{~K}$ asper, jw., s. 92.

${ }^{13}$ K. Rah ne r, Recht, [w:] Lexikon für Theologie und Kirche, t. 8, Freiburg 1967, s. 1033; Por. W. A y m a n s, Kirche - das Recht im Mysterium der Kirche, [w:] Handbuch des katholischen Kirchenrechts, Regensburg 1983, s. 9. 
czy wyposażonych we władzę przez święcenia biskupie. Nie zmienia to jednak teologicznej kwalifikacji odnośnej struktury, czy to synodu biskupów, czy też konferencji biskupów. To, czym poszczególny biskup dysponuje dzięki potestas sacra czy dzięki teologicznej władzy, nie przechodzi na gremium, w którym uczestniczy. Inaczej rzecz ujmując, gremium, w którym uczestniczą biskupi, nie otrzymuje z teologicznej jakości poszczególnych biskupów własnej teologicznej jakości. Przyznanie teologicznej jakości, znajdujące uzasadnienie w ius humanum, nie jest przekazywalne. Ustanowienie i formalne określenie konferencji biskupów znajduje swoje uzasadnienie w prawie ludzkim, w ius mere ecclesiasticum (por. kan. 447 - 449). Z tego względu należy zakwestionować opinię kanonisty z Eichstätt P. Krämera ${ }^{14}$, który pisze, że władza, jaką sprawuje konferencja biskupów, jest lokalną kościelną władzą biskupią z prawa Bożego. Tego rodzaju sformułowanie pospiesznie wiąże lokalną kościelną władzę biskupią $\mathrm{z}$ konferencją biskupów, nie posiadającą żadnej kolegialnej władzy w sensie wypowiedzi soborowych.

Moim zdaniem — różniącym się od całej grupy znanych teologów niemieckojęzycznych - konferencja biskupów ma dużą jakość prawną, znajdującą swoje uzasadnienie w synodalnej tradycji Kościoła. Ta jakość wszakże ma swoje uzasadnienie w ius mere ecclesiasticum. Autorytet konferencji biskupiej uczestniczy w autorytecie pojedynczego biskupa Kościoła lokalnego, jak również w autorytecie kolegium biskupów połączonych z papieżem, tj. kolegium Kościoła światowego; jednakże konferencja biskupia jako taka nie stanowi kolegium w sensie II soboru watykańskiego. Dlatego nie mogę jej przyznać teologicznego uzasadnienia. Ma ona - jak to powiedział kard. Frings na soborze ${ }^{15}$ — duże znaczenie dla lokalnych organizacji kościelnych, dla lokalnych Kościołów danego kraju, dla ich duchowego życia i pracy duszpasterskiej. Przypada zatem konferencji znaczenie, które ma uzasadnienie prawne i pastoralne, ale nie teologiczne we właściwym tego słowa znaczeniu.

\section{ad 2: Uzasadnienie prawne}

Ponieważ konferencje biskupie nie mogą mieć teologicznego uzasadnienia, dlatego problem ich uzasadnienia prawnego jest znacznie łatwiejszy. W kanonie $381 \S 1$, określającym władzę biskupią w Kościele lokalnym (ecclesia localis), jest powiedziane wyraźnie, że biskup sprawuje swoją władzę w Kościele lokalnym ,z wyjątkiem tego, co z samego prawa albo na skutek zarządzenia pa-

${ }^{14}$ Krämer, jw., s. 406; por. także: W. A y mans, Wesensverständnis und Zuständigkeiten der Bischofskonferenz im Codex Iuris Canonici von 1983, "Archiv für Katholisches Kirchenrecht" 152:1983, s. 46 - 61; H. Mülle r, Diözesanbischof - Bischofskonferenz, ,Theologische Quartalsschrift” 168:1988, s. 215 - 229; H. J. P ot t m e y e r, Was ist eine Bischofskonferenz, „Stimmen der Zeit" 206:1988, s. $435-446$.

${ }^{15}$ Zob. wyżej przypis 8. 
pieskiego czy też wyższego lub innego autorytetu kościelnego zostało wyjęte z jego kompetencji".

Winfried Aymans, kanonista z Monachium, zestawil kompetencje konferencji biskupich w ujęciu nowego Kodeksu prawa kanonicznego i podzielił je według poszczególnych ksiąg tego Kodeksu ${ }^{16}$. Wskazał on także na prawa współdziałania występujące w nowym Kodeksie np. kiedy w grę wchodzą rozstrzygnięcia Stolicy Apostolskiej (np. przy mianowanu biskupów; kan. 377 $\S 2, \S 3)$.

Mimo że ustanowienie konferencji biskupich zostało podjęte dopiero na II soborze watykańskim i obecnie znalazło swoje prawne oparcie w nowym $\mathrm{Ko}$ deksie prawa kanonicznego, to jednak ustanowienie spotkań biskupów znajduje swoje uzasadnienie w tradycji Kościoła oraz w prawnych formach plenarnych i prowincjalnych synodów. II sobór watykański wyraził życzenie, aby te synody i konferencje, ,instituta novo vigeant robore, quae aptius et efficacius fidei incremento disciplinaeque conservationi in variis Ecclesiis, pro temporum adiunctis, provideatur" (Christus Dominus, 36). Sobór wyraził także życzenie, aby nadal zachowano istniejące formy plenarnych i prowincjalnych synodów. Jednakże dosyć trudne ukazuje się rozgraniczenie zadań tych synodów w stosunku do ustanowionych aktualnie konferencji biskupich. Dokument studyjny kongregacji biskupów wskazuje na biskupie święcenia uczestników jako cechę odróżniającą. Ta cecha odróżnia, jeżeli uwzględni się „canones”, jest trudna do utrzymania, dlatego należy się rozglądać za innymi kryteriami.

Nie istnieje wszakże potrzeba dalszego uzasadnienia konferencji biskupich. Dzięki II soborowi watykańskiemu (por. Christus Dominus, 37) znalazła ona w nowym Kodeksie prawa kanonicznego swoje trwałe miejsce (por. kan. 447 - 459). Prawne uzasadnienie znajduje się w tradycji Kościoła, która choć nie zawsze ta sama, to przecież znała podobne struktury. II sobór watykański postawił niejako końcowy punkt na drodze długiego rozwoju tych konferencji. Konferencje biskupie są powoływane na gruncie ius humanum, albo dokładniej powiedziawszy - ius mere ecclesiasticum. Ich zróżnicowanie i znaczenie w stosunku do innych synodalnych struktur musi się uzewnętrznić w dalszym praktycznym rozwoju.

\section{ad 3: Pytanie o nauczycielski autorytet konferencji biskupów}

Trzecie pytanie narzuca się z kan. 753 i schematu przedstawionego przez Kongregację biskupów na temat autorytetu nauczycielskiego konferencji biskupich.

Schemat Kongregacji biskupów wychodzi z refleksji, że biskup w swoim

${ }^{16}$ A y mans, Wesensverständnis und Zuständigkeiten, s. 54-61. 
Kościele lokalnym reprezentuje także w urzędzie nauczycielskim całe kolegium biskupów. Trafnie sformułował to Winfried Aymans. Powiada on, że w Kościele lokalnym jest obecne treściowo całe posłannictwo Kościoła w słowie i sakramentach ${ }^{17}$. Oznacza to, że na mocy autorytetu biskupa w Kościele lokalnym dokonuje się treściowo to samo przepowiadanie wiary, co i w całym Kościele.

Urząd nauczycielski biskupa - powiada Kongregacja biskupów w swoim dokumencie - jest pośredniczony ex opere operato, jako ontologiczny podarunek Ducha prawdy w święceniach biskupich. Należy przy tym podkreślić tutaj uwagę, że każdy biskup reprezentuje z kolei całe kolegium i że to jest gwarantowane tylko wiernym posłuszeństwem względem biskupa Rzymu i w kontynuacji kolegium apostolskiego.

Instrumentum laboris Kongregacji biskupów cytuje kan. 753 odnośnie do konferencji biskupich, stwierdzając: biskupi są autentycznie głosicielami i nauczycielami powierzonych im wiernych, mimo że nie dysponują nieomylnością w nauczaniu. Konferencje biskupie nie mają także urzędu nauczycielskiego we właściwym znaczeniu tego słowa. Ta wypowiedź jest zgodna z kan. 753, gdzie mowa o obowiązku przepowiadania biskupów. Biskupi głoszą wiarę albo pojedynczo, albo z okazji spotkania na konferencjach i podczas synodów partykularnych. Sama konferencja biskupów — twierdzi dokument - nie ma koniecznej prawno-ustrojowej struktury, ani dogmatycznej podstawy, w przeciwieństwie do kolegium biskupów powiązanego z urzędem Piotra. Konferencja biskupów nie może zastępować poszczególnego biskupa i jego odpowiedzialności jako głosiciela i nauczyciela wiary. Powstaje więc pytanie, czy sformułowanie kan. 753, które wychodzi z autorytetu nauczycielskiego zgromadzonych na konferencji biskupów, powinno zostać dokładniej zinterpretowane przez dokument i czy ta interpretacja ma jakieś ograniczenia. Sformułowanie kan. 753 wydaje się otwarte, zarówno na interpretację autorytetu nauczycielskiego konferencji biskupów, jak i na autorytet nauczycielski poszczególnego biskupa, zbierającego się z innymi biskupami na niekoniecznej z prawno-ustrojowego punktu widzenia konferencji biskupów. A zatem kan. 753 można przytaczać na uzasadnienie obu poglądów. Ogólnie rzecz biorąc, można powiązać magisterium authenticum $\mathrm{z}$ konferencją biskupów. Dokument kongregacji nie chce wszakże wyraźnie uznać tego powiązania.

Kard. Ratzinger, w cytowanym już wywiadzie z 1984 r., oświadczył: „Konferencja biskupów nie ma jako taka urzędowej funkcji nauczania. Odpowiednie dokumenty zawdzięczają swoją powagę tylko wspólzgodzie, która zostaje jej udzielana przez poszczególnych biskupów"18. Ten pogląd - jak się wydaje — można znaleźć w dokumencie Kongregacji biskupiej.

17 A y man s, Gliederungs- und Organisationsprinzipien, [w:] Handbuch des Katholischen Kirchenrechts, Regensburg 1983, s. 240.

${ }^{18} \mathrm{R}$ at zinge r, Zur Lage des Glaubens..., s. 59 n. 
Hermann Josef Pottmeyer, profesor teologii fundamentalnej z Bochum, odczytuje ze sformułowań dokumentu, że konferencje biskupie są jedynie pastoralnymi albo ogólnymi teologicznymi gremiami doradczymi biskupów ${ }^{19}$. Niemniej na tego rodzaju stopniowanie sam Pottmeyer nie wyraża zgody. Widzi on zadanie konferencji biskupów w tym, by ewangelię i kościelną naukę wykładać w konkretnej sytuacji regionu oraz by „odczytywać w niej znaki czasu". To także należy do urzędu nauczycielskiego. Oczywiście i Pottmeyer musi się zgodzić, że konsens konferencji biskupów nie jest dla każdego biskupa zobowiązujący. Czyni to, uznając „że w tym przypadku musiałoby się odstąpić od powszechnie obowiązującej nauki wiary" 20 . Tym samym wyraźnie zostaje stwierdzone, że nauczycielską odpowiedzialność każdego biskupa nie można zastąpić przez opisany autorytet konferencji biskupów. Chociaż Pottmeyer wydaje się skłaniać do poglądu o autorytecie nauczycielskim konferencji biskupów - przy tym może się on powołać na kan. 753 - to przecież dostrzega on wyraźnie alternatywę, że poszczególni biskupi mogą te kompetencje, ten autorytet nauczycielski zakwestionować własnym rozstrzygnięciem. Stąd widać $\mathrm{z}$ jednej strony napięcie między biskupem i konferencją biskupów, a z drugiej strony staje się jasne, że autorytet nauczycielski w sprawach wiary przysługuje tylko wtedy konferencji biskupów, kiedy wszyscy biskupi wyrażą na to swą zgodę. Z kanonicznego punktu widzenia można się spierać co do tego, czy autorytet nauczycielski realizuje się w zwykłej równoczesnej akcji zgromadzonych na konferencji biskupów, czy też jest działaniem kolegium ${ }^{21}$, co nie zmienia nic w odpowiedzialności każdego biskupa z osobna.

Jeżeli przeciwstawi się poglądy Pottmeyera zapatrywaniu kard. Ratzingera, to powstaje pytanie, czy ich stanowiska tak dalece są od siebie oddalone, jakby się to wydawało na pierwszy rzut oka. Także Pottmeyer - konsekwentnie do swoich poglądów - uznaje prawo każdego biskupa, ponieważ autorytet nauczycielski konferencji biskupów tylko wtedy może zostać uznany, jeżeli wszyscy bez wyjątku biskupi zgadzają się na oświadczenie doktrynalne konferencji. Tym samym znowu ukazuje się całe napięcie istniejące na linii biskupkonferencja biskupów.

\section{VII}

Przytoczone wywody nie nawiązują do dyskusji, które zostały wywołane dopiero w związku z pojawieniem się instrumentum laboris Kongregacji biskupów, lecz sięgają do auli II soboru watykańskiego, kiedy to po raz pierwszy wy-

${ }^{19}$ Pottmeyer, jw., s. 443.

20 Tamże. 248.

${ }^{21}$ Por. U. R u h, Wenn Kollegialität konkret wird, „Herder Korrespondenz” 42:1988, s. 245 - 
łoniło się pytanie o instytucjonalizację konferencji biskupów ${ }^{22}$. Zostało ono wyraźnie podjęte na nadzwyczajnym synodzie biskupów w roku 1985, gdzie zajęto się tą problematyką ${ }^{23}$. Pytanie to pojawia się także w publikacjach ${ }^{24}$, podejmujących $w$ tym czasie ten problem. Tylko do niektórych $\mathrm{z}$ nich nawiązałem.

Ostatecznie idzie tu o napięcie pomiędzy collegium episcoporum i conferentia episcoporum $\mathrm{z}$ jednej strony, a conferentia episcoporum $\mathrm{i}$ episcopi $\mathrm{z}$ drugiej strony. Istniejących napięć nie da się usunąć przez same tylko stwierdzenia, że teologiczne i kanonistyczne poglądy jednego autora uzna się za konserwatywne, drugiego zaś autora za postępowe. Napięcia należy przetrzymać i wyjaśnić; one należą do życia Kościoła. Ostatecznie idzie o Kościół i jego misję zbawczą. Kościół potrzebuje w tym celu urzędów, gremiów, instytucji, które z biegiem historii Kościoła stają się coraz bardziej widoczne. Konferencja biskupów tak jak ona została konkretnie określona w Kodeksie prawa kanonicznego na polecenia II soboru watykańskiego - nie ma jeszcze długiej historii. Może właśnie dlatego jest tak trudne jej teologiczne uporządkowanie.

Ttumaczyt ks. Adam Kubiś

${ }^{22}$ Por. wyżej przypis i interwencję kard. Fringsa; nadto H. de Lu b a c, Les églises particulières dans l'Église universelle, Paris 1971.

${ }^{23}$ Por. K a s p e r, jw., s. 39; nadto por. stanowisko w tej sprawie zajęte przez Międzynarodową Komisję Teologiczną: Internationale Theologenkommission. Mysterium des Gottesvolkes, Einsiedeln 1987.

${ }^{24}$ Prócz cytowanych wyżej publikacji zob.: W. Kas pe r, Der theologische Status der Bischofskonferenzen, ,Theologische Quartalsschrift” 167:1987, s. 1-6; H. J. P o t t m e y e r, H. Müll e r (Hrgs.), Die Bischofskonferenz, Düsseldorf 1989; D. B. Murr a y, The Legislative Authority of the Episcopal Conference, „Studia Canonica” 20:1986, s. 33-47; H. T e is si e r, Die Bischofskonferenzen und ihre Funktion in der Kirche, "Concilium” 22:1986, s. $481-486 ;$ H. Sch mit z, Status Theologicus et Juridicus Conferentiarum Episcopalium. Kanonistische Bemerkungen zu einem Arbeitspapier der Kurienkongregation für die Bischöfe, „Archiv für katholisches Kirchenrecht” 156:1987, s. 515 - 521; K. W alf, Gefährdete Kollegialität, „Orientierung” 52:1988, s. 223 - 224; S. W o o d, The Theological Foundations of Episcopal Conferences and Collegiality, „Studia Canonica" 22:1988, s. 327 - 338 . 